\title{
Plasma membrane receptor mediated MAPK signaling pathways are activated in human uterine cervix at parturition Hong Wang ${ }^{1,3}$ and Ylva Vladic Stjernholm*2
}

Address: ${ }^{1}$ Division for Reproductive Endocrinology, Karolinska University Hospital and Karolinska Institutet, SE-171 76 Stockholm, Sweden, ${ }^{2}$ Division for Obstetrics and Gynecology, Department of Woman and Child Health, Karolinska University Hospital and Karolinska Institutet, SE17176 Stockholm, Sweden and ${ }^{3}$ Department of Cell and Molecular Biology, Karolinska University Hospital and Karolinska Institutet, SE-171 76 Stockholm, Sweden

Email: Hong Wang - hong.wang@cgb.ki.se; Ylva Vladic Stjernholm* - ylva.vladic-stjernholm@karolinska.se

* Corresponding author

Published: 28 January 2007

Reproductive Biology and Endocrinology 2007, 5:3 doi:10.1 186/1477-7827-5-3

This article is available from: http://www.rbej.com/content/5/l/3

(C) 2007 Wang and Stjernholm; licensee BioMed Central Ltd.

This is an Open Access article distributed under the terms of the Creative Commons Attribution License (http://creativecommons.org/licenses/by/2.0), which permits unrestricted use, distribution, and reproduction in any medium, provided the original work is properly cited.
Received: 25 October 2006

Accepted: 28 January 2007

\begin{abstract}
Background: Cervical ripening resembles an inflammatory reaction. Estrogens induce leukocyte migration into tissue and factors promoting cervical remodeling and labor, although the mechanisms are only partially known. The aim of this study was to investigate whether plasma membrane receptor mediated pathways, known to be activated by estrogens and proinflammatory compounds, are involved in cervical ripening before labor.
\end{abstract}

Methods: The expression and distribution of mitogen activated protein kinases (MAPK), which transduce extracellular signals into intracellular responses through phosphorylation, and their intracellular targets transcription factors c-Jun and c-Fos proteins (AP-I) were analysed in cervical biopsies from term pregnant women (TP), immediately after parturition (PP), and from nonpregnant women (NP). Immunohistochemistry and RT-PCR techniques were used.

Results: Cell-specific alterations in the immunostaining pattern for MAPK were observed. The expressions of activated, phosphorylated MAPK forms pERKI/2, PJNK and P38MAPK were significantly increased in cervical stroma until TP and PERKI/2 expression was significantly enhanced in PP group. c-Jun was significantly increased in cervical stroma and smooth muscle in TP as compared to NP group. c-Fos was significantly increased in stroma, squamous epithelium and glandular epithelium in PP as compared to TP group.

Conclusion: We report, for the first time, cell-specific activation of PMAPKs and their targets transcription factors c-Fos and c-Jun (AP-I) proteins in human uterine cervix until term pregnancy, and immediately after parturition. These results suggest a role for MAPK activation in cervical ripening before labor.

\section{Background}

Cervical remodeling is a prerequisite for effacement and dilatation prior to labor and is characterized by an increase in vascular adhesion molecules, diapedesis and activation of neutrophils, T-cells, monocytes/macro- phages, mast cells, eosinophils, and increased concentrations of metalloproteinases [1-5].

Metalloproteinase enzymes effectuate an altered proteoglycan composition and increased collagen solubility, 
which allows for extracellular matrix remodeling and an increased cervical distensability [5-8]. Maternal plasma levels of estrogens increase exponentially until term pregnancy and at labor concomitant with unchanged or decreased progesterone levels $[7,9,10]$. The exact mechanisms leading to parturition in humans remain unclear, although previous studies have proposed that estrogens may contribute to extracellular matrix remodeling and inflammatory changes [1,10-12]. The suggested effects of estrogens during cervical ripening appear to be highly celltype specific $[11,12]$.

Mitogen activated protein kinases (MAPK) comprise proline-directed second messenger systems, used by eukaryotic cells for the transduction of extracellular signals into responses in the cytosol, nucleus and mitochondria through protein phosphorylation [13-16]. Factors eliciting MAPK signal transduction are identified including proinflammatory cytokines, growth factors, estrogens, and mitochondrial reactive oxygen species (ROS) e.g. thioredoxin [14-17]. The most well-characterized MAPK cascade consists of extracellullar signal-regulated (ERK) kinases MEK1/2 and ERK 1/2 (p42/p44), stress-activated protein kinases (SAPK) i.e. c-Jun amino-terminal kinase (JNK) and reactivating protein kinase (p38MAPK) [1315]. Activation of MAPKs is mediated by upstream phosphorylation via MAPK kinases (MAPKKs) $[14,15,18,19]$. Once activated, MAPKs predominantly regulate gene expression via phosphorylation of downstream transcription factors, which include the proinflammatory transcription factors activator protein (AP)-1 and nuclear factor (NF)- $\mathrm{B}[15,16,19,21,22]$. AP-1 is a collective term referring to heterodimers formed by c-Jun, c-Fos or activating transcription factor subunits which bind to AP-1 responsive elements in gene promoters [17-20]. Despite the high maternal plasma estradiol level present at term pregnancy, the total nuclear estrogen receptor (ER) level in the uterine cervix is markedly decreased as compared to non-pregnant, suggesting a markedly limited nuclear ER mediated biological response to estrogens at parturition $[7,9]$. The aim of this study was to investigate the expression and distribution of MAPKs and their intracellular target transcription factor AP-1.

\section{Materials and methods \\ Patients}

The non-pregnant (NP) group consisted of healthy, regularly menstruating women $(n=6)$ without medication, undergoing hysterectomy due to benign disorders not involving the cervix. Hysterectomies were carried out during the follicular phase of the menstrual cycle within ten days from the latest menstrual period, to avoid the risk for an unknown pregnancy. The study subjects had a mean age of 42 years (range 32-49), and a mean parity of 2 (13 ). The term pregnant (TP) group consisted of healthy women $(\mathrm{n}=8)$ with a mean age of 32 years (range 2838 ), a mean gestational age of 38 weeks (range 37-39), and a mean parity of 1 (range 1-2). All had unripe cervices as determined by a Bishop score of $<5$ points and none of them was in labor. Elective caesareans on medical indications were carried out in all women. The postpartum (PP) group consisted of primiparous, healthy women $(\mathrm{n}=9)$ with uncomplicated pregnancies, from whom biopsies were obtained within 20 minutes after uncomplicated vaginal parturition. They had a mean age of 30 years (range 23-37), and a mean gestational age of 40 weeks (range 39-41).

Every woman had given her informed consent before entering the study. The study was approved by the Karolinska Hospital Ethics Committee (96-187, 99-099).

\section{Sampling procedure}

The biopsies were obtained transvaginally from the anterior part of the uterine cervix at the 12 o'clock position, from 10-20 mm depth. The cervical biopsies were divided and one half was immersion-fixed in $4 \%$ formaldehyde at $4^{\circ} \mathrm{C}$ overnight, stored at $4{ }^{\circ} \mathrm{C}$ in $70 \%$ ethanol and thereafter embedded in paraffin. One half was immediately frozen at $-70^{\circ} \mathrm{C}$.

\section{Immunohistochemistry}

Paraffin sections ( $5 \mu \mathrm{m}$ ) were used as a standard immunohistochemical technique (avidin-biotin-peroxidase) which was carried out as described before to visualize MAPK (p42/44-ERK1/2, p38 and JNK) immunostaining intensity and distribution [23]. Primary antibodies used in this study are listed in Table 1 . All antibodies were incubated at $4{ }^{\circ} \mathrm{C}$ overnight. Replacement of the primary antibody with an equivalent concentration of non-immune mouse IgG (for monoclonal antibody) and rabbit IgG (for polyclonal antibody) was used for negative controls.

\section{Immunostaining analysis}

A Leica microscope and Sony video camera (Park Ridge, NJ, USA) connected to a computer (Leica Imaging System Ltd, Cambridge, UK) was used to assess immunohistochemistry results. Two sections of each sample were analysed and ten areas of cell compartment from each section were randomly chosen for quantification of immunostaining intensity. The staining intensity was semiquantitatively graded (H.W.) by manual scoring as very strong (4) when $80-100 \%$ cells were positive, strong (3) when $60-$ $80 \%$ of cells were positive, moderate (2) when $30-60 \%$ of cells were positive, weak (1) when less than $30 \%$ of cells were positive or as no staining (0).

\section{RNA isolation and RT-PCR analyses}

Frozen pieces of cervical tissue were processed for isolation of total RNA according to the manual for the SV total 
Table I: Primary antibodies used in this study.

\begin{tabular}{|c|c|c|c|}
\hline Antibody & Specificity & Dilution & Sources \\
\hline $\begin{array}{l}\text { c-fos (Ab-2) Polyconal } \\
\text { (PC05) }\end{array}$ & Amonio acid residues $4-17$ of human c-Fos & $\mathrm{I}: 40$ & $\begin{array}{l}\text { Oncogene Research Products, } \\
\text { Cambridge, MA }\end{array}$ \\
\hline $\begin{array}{l}\text { C-Jun (Ab-2) Polyclonal } \\
\text { (PC07) }\end{array}$ & Amonio acid residues $91-105$ of human c-Jun & $1: 40$ & $\begin{array}{l}\text { Oncogene Research Products, } \\
\text { Cambridge, MA }\end{array}$ \\
\hline $\begin{array}{l}\text { Phopho-specific P44/42 MAPK polyclonal Ab } \\
\text { (9I0IS) }\end{array}$ & $\begin{array}{l}\text { Amonio acid residues } 91-105 \text { of human p44 MAP } \\
\text { kinase, detects p } 42 \text { and p44 MAPK (ErkI and Erk2), } \\
\text { only when activated by phosphorylation at Thr } 202 \\
\text { and Tyr } 204\end{array}$ & $\mathrm{I}: 250$ & $\begin{array}{l}\text { New England Biolabs, Inc. } \\
\text { Beverly, MA }\end{array}$ \\
\hline $\begin{array}{l}\text { P44/42 MAPK polyclonal Ab } \\
(9102)\end{array}$ & $\begin{array}{l}\text { Amonio acid residues } 345-358 \text { of rat p42 MAPK, } \\
\text { detects total MAP kinase (Erk I and Erk2) levels }\end{array}$ & $\mathrm{I}: 1000$ & $\begin{array}{l}\text { New England Biolabs, Inc. } \\
\text { Beverly, MA }\end{array}$ \\
\hline $\begin{array}{l}\text { Phospho-p38 MAPK polyclonal Ab } \\
\text { (92IIS) }\end{array}$ & $\begin{array}{l}\text { A synthetic doubly phosphorylated peptide (Thr 180/ } \\
\text { Tyr 182) of human p38 MAPK }\end{array}$ & $\mathrm{I}: 500$ & $\begin{array}{l}\text { New England Biolabs, Inc. } \\
\text { Beverly, MA }\end{array}$ \\
\hline $\begin{array}{l}\text { P-JNK (G-7) Monoclonal AB } \\
\text { (sc-6254) }\end{array}$ & $\begin{array}{l}\text { A short aa sequence containing phosphorylated on } \\
\text { Thr-I83 and Tyr-185 of JNKI of human, reacts to } \\
\text { phosporylated JNK I-3 }\end{array}$ & $\mathrm{I}: 250$ & $\begin{array}{l}\text { Santa Cruz Biotechnology, Inc. } \\
\text { USA }\end{array}$ \\
\hline $\begin{array}{l}\text { JNK2 (D-2) Monoclonal AB } \\
\text { (sc-7345) }\end{array}$ & Full lengh (aa I-424) human JNK2, reacts to JNKI-3 & $\mathrm{I}: 250$ & $\begin{array}{l}\text { Santa Cruz Biotechnology, Inc. } \\
\text { USA }\end{array}$ \\
\hline
\end{tabular}

RNA isolation system (Promega, Madison, WI, USA). One $\mu \mathrm{g}$ of total RNA were reversely transcribed at $42^{\circ} \mathrm{C}$ for 45 min in a final volume of $40 \mu \mathrm{l}$ with a reaction mixture containing $50 \mathrm{mM}$ Tris- $\mathrm{HCl} \mathrm{pH} \mathrm{8.3,75} \mathrm{mM} \mathrm{KCl,} 3 \mathrm{mM}$ $\mathrm{MgCl}_{2}, 7.5 \mathrm{mM}$ DTT, $0.5 \mathrm{mM}$ dNTPs, $1 \mu \mathrm{g}$ random hexamers and 400 IU of ML-MTV reverse transcriptase (GIBO, BRL, Paisley, UK). Primer sequences and the predicted product size were for human c-fos gene: 5'-GGATAGCCTCTCTTACTACCAC-3'; 5'-TCCTGTCATGGTCTTCACAACG-3' and $280 \mathrm{bp}$; the human c-jun gene: 5'GGAAACGACCTTCTATGACGATGCCCTCAA-3'; 5'GAACCCCTCCTGCTCATCTGTCACGTTCTT-3' which amplify a $325 \mathrm{bp}$ fragment and the human ribosomal protein S28 which was used as an internal control: 5'GTGCAGATCTTGGTGGTAGTAGC-3'; 5'-AGAGCCAATCCTTATCCCGAAGTT-3' and 552 bp. For PCR amplification, the cDNA (corresponding to 50 ng RNA from the RTPCR reaction) was added to the reaction mixture containing $20 \mathrm{mM}$ Tris-HCl pH 8.4. $50 \mathrm{mM} \mathrm{KCl,} \mathrm{2.5} \mathrm{IU} \mathrm{Tag} \mathrm{DNA}$ polymerase (GIBCO, BRL, Paisley, UK), $0.2 \mathrm{mM}$ dNTPs, $1.5 \mathrm{mM} \mathrm{MgCl}$, and oligonucleotide primer pairs (50 $\mathrm{pmol} /$ pair), with a final volume of $50 \mu \mathrm{l}$. PCR was performed for 30 cycles using $94^{\circ} \mathrm{C}(30 \mathrm{~s})$ for denaturing, $58^{\circ} \mathrm{C}(45 \mathrm{~s})$ for annealing, $72^{\circ} \mathrm{C}(45 \mathrm{~s})$ for extension and a final incubation at $72^{\circ} \mathrm{C}$ for 3 min on a thermal cycler. The products were subjected to electrophoresis in $2.5 \%$ agarose gels; data were analyzed using a Fujifilm Las- 1000 system (Fujifilm, Japan). Statistical analyses were not performed on this data.

\section{Statistical analyses}

Statistical calculations for the immunohistochemistry results by image analysis of pMAPK were performed by ANOVA on ranks (Kruskal-Wallis test) and significances were evaluated by Dunn's test. One-way parametric
ANOVA was used for analyses of immunohistochemistry results for c-Jun and c-Fos proteins.

\section{Results}

All three types of phosphorylated MAPKs were positively stained in the cervix, in both cell nuclei and cytoplasm (Figure 1 and 2). The distribution of pMAPKs by using different antibodies in the cervical connective tissue was described as following:

\section{ERKI/2 (p42/44)}

ERK immunostaining was observed in different compartments of the cervix by using non-phosphorylated and phosphorylated (pERK1/2) antibodies. The staining intensity was slightly higher by the non-phosphorylated antibody (data not shown), although the staining patterns did not differ significantly by these two types of antibodies. In cervical stroma, pERK1/2 expression was the lowest in the NP group, and increased in TP and PP groups as compared to NP $(\mathrm{P}<0.05)$ (Figure $1 \mathrm{~A}-\mathrm{D}$ and Figure $3 \mathrm{~A})$. In the subepithelial mucosa area, intensive immunostaining was present in the stromal cells in all study groups. In smooth muscle, the pERK1/2 expression was unchanged between the groups (data not shown). The endothelial cells of blood vessels (vein) displayed high pERK1/2 expression in NP group, but weak or absent in TP and PP groups as compared to NP $(\mathrm{P}<0.01)$ (Figure $1 \mathrm{~A}, \mathrm{C}$ and Figure 3A). No immunostaining for pERK $1 / 2$ was found in glandular epithelium (Figure 1B,D).

\section{JNK}

The phosphorylated JNK (pJNK) immunostaining was mainly localized to the cell nuclei, whereas non-phosphorylated JNK staining was found in both cytosol and nuclei (data not shown). In cervical stroma, pJNK expression was 

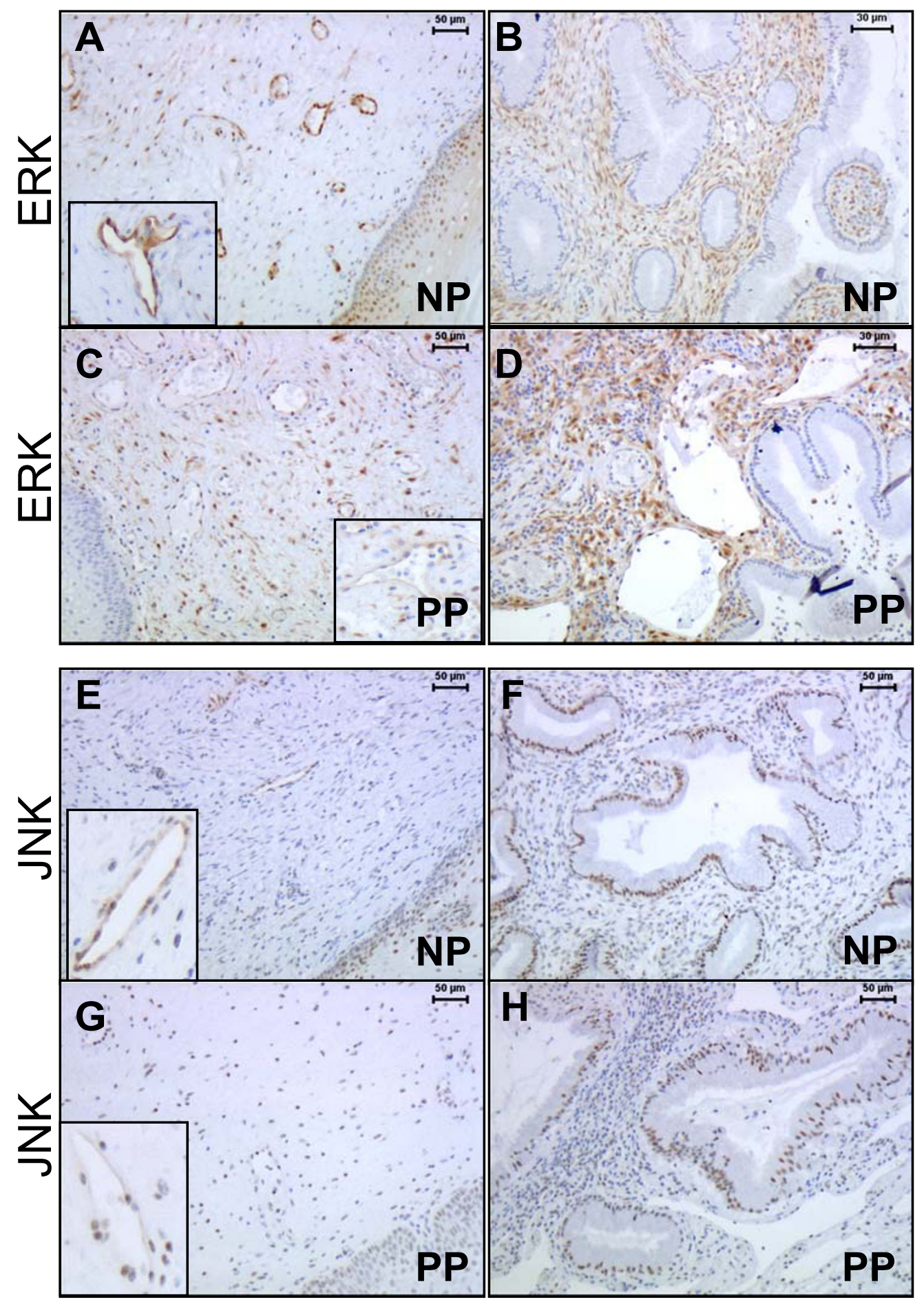

Figure I

Representative sections showing the expression and distributions of pERK and pJNK in different cell types of the uterine cervix by using phospho-antibodies, as shown in non-pregnant (NP) and postpartum (PP) groups. Cervical stroma, blood vessels shown in A, C, E, G. Glandular epithelium and subepithelial mucosa area of stroma shown in $B, D, F$ and $H$. 

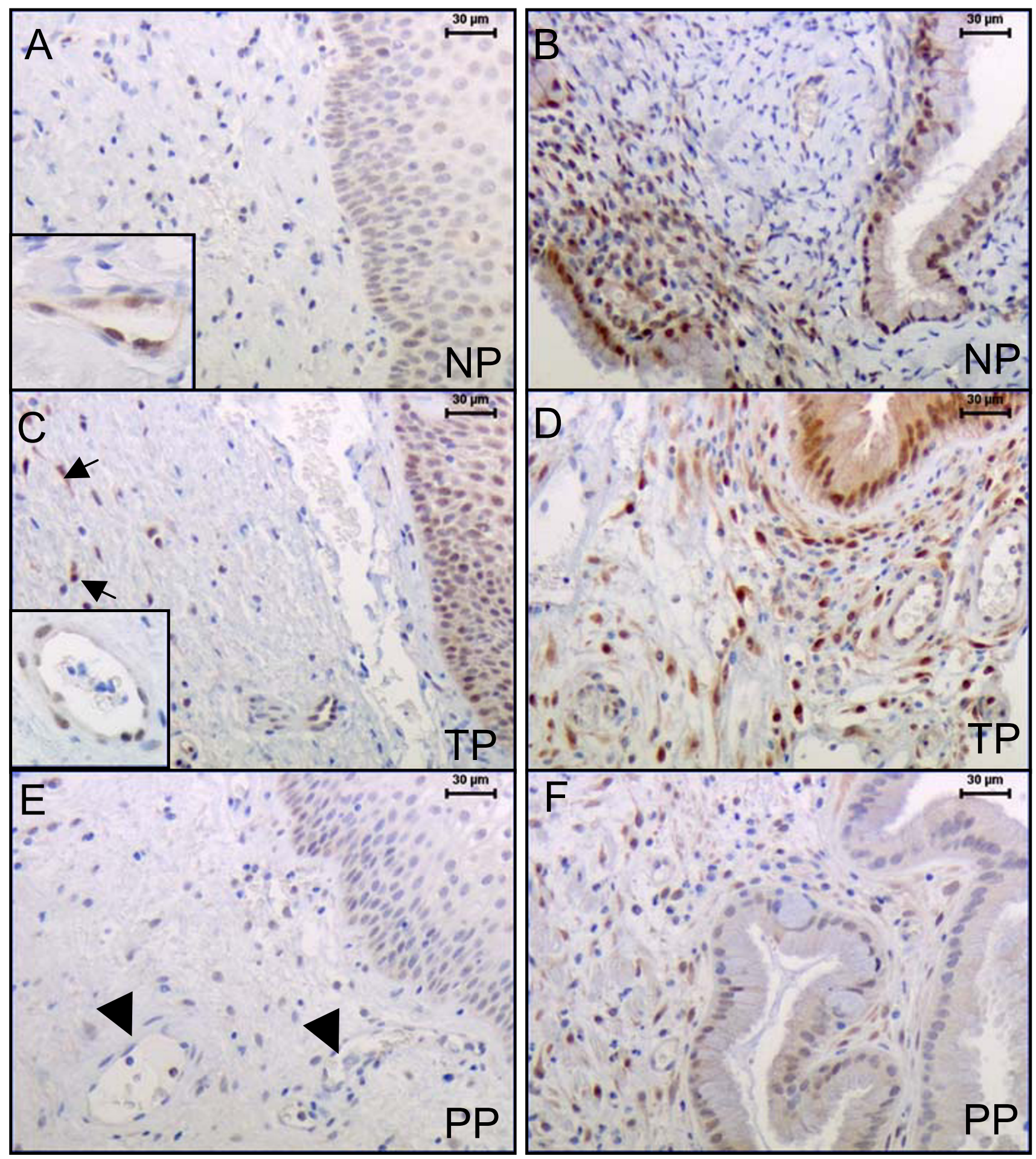

Figure 2

Representative cervical sections from non-pregnant (NP) (A-B), term pregnant (TP) (C-D) and postpartum (PP) groups (E-F), showing the the expression and distribution of p38MAPK in different cells by using phospho-antibodies. Stroma and blood vessels (A, C and E). Glandular epithelium and subepithelial mucosa area of stroma (B, D and F). 


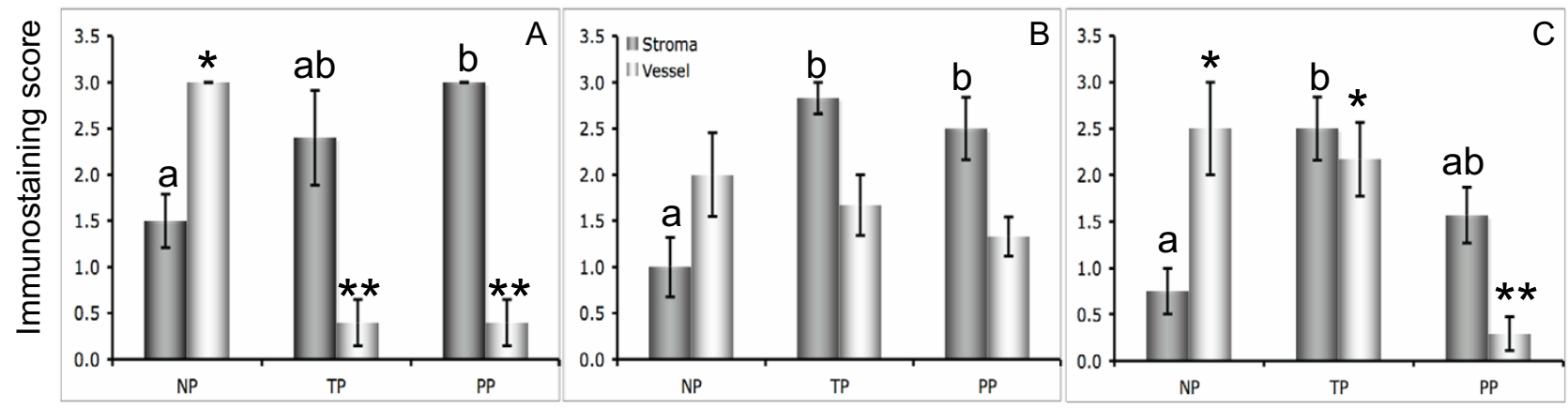

Figure 3

The immunostaining scores for pERKI/2 (A), PJNK (B) and p38MAPK (C) in cervical stroma and vascular endothelium in biopsies from non-pregnant (NP, $n=6)$, term pregnant $(T P, n=8)$ and postpartum $(P P, n=9)$ groups respectively. For stroma figures with different letter designation are significantly different $(P<0.05)$. For blood vessels significant values are marked with $*$ for $P<0.05$, and with $* *$ for $P<0.0$ I respectively.

the lowest in the NP group, but significantly increased and high in TP and PP groups as compared to NP $(\mathrm{P}<0.05)$ (Figure 1E-H and Figure 3B). In the subepithelial mucosa area, pJNK staining was present in some stromal cells in all study groups. High intensity pJNK staining was generally found in glandular epithelium but without significant changes between the study groups (Figure $1 \mathrm{~F}, \mathrm{H}$ ). Vascular endothelial pJNK expression did not differ between the groups (Figure 1E,G and Figure 3B).

\section{p38MAPK}

Only the phosphorylated-specific antibody for p38MAPK was used. A reciprocal pattern för p38MAPK expression was observed in cervical stroma in comparison to vascular endothelium between NP and TP groups (Figure 3C). High intensity p38MAPK immunostaining was present in the vascular endothelium in NP and TP groups and absent in PP group $(\mathrm{P}<0.01)$ (Figure $2 \mathrm{~A}, \mathrm{C}$ (magnification), $\mathrm{E}$ (arrow head), and Figure 3C). p38MAPK expression in stroma was significantly increased in TP as compared to NP group $(\mathrm{P}<0.05)$ (Figure 2 and Figure $3 \mathrm{C})$. In the subepithelial mucosa area, p38MAPK staining was present in stroma cells in all study groups, but less intensive in the PP group (Figure 2B,D,F).

\section{c-Jun}

Immunoreactivity for c-Jun protein was present in all cellular compartments in NP, TP and PP groups (Figure 4). cJun expression was significantly increased in cervical stroma $(\mathrm{P}<0.01)$ and smooth muscle $(\mathrm{P}<0.001)$ in TP as compared to NP group (Figure 5). The changes in vascular endothelium, squamous epithelium and glandular epithelium did not differ between the groups.

\section{c-Fos}

Immunoreactivity for c-Fos protein was present in all cellular compartments in NP, TP and PP groups, as shown in Figure 4. c-Fos expression was increased in cervical stroma $(\mathrm{P}<0.01)$, squamous epithelium $(\mathrm{P}<0.01)$ and glandular epithelium $(\mathrm{P}<0.05)$ in $\mathrm{PP}$ as compared to TP group (Figure 6). The changes in vascular endothelium and smooth muscle did not differ between the groups.

\section{RT-PCR}

Figure 7. illustrates the presence of c-jun and c-fos mRNAs in human uterine cervix in term pregnancy and immediately after parturition. S28 was used as a standard to enable comparison of the amount of RNA loaded to each well.

\section{Discussion}

This study demonstrates alterations in the expression and distribution of the phosphorylated, activated MAPK forms and in their intracellular target transcription factor AP-1 in human uterine cervix at term pregnancy and immediately after parturition. To our knowledge, this is the first study identifying pMAPK activation in human uterine cervix. Rusycky [24] was the first to report an increase in MAPK cascade in vivo in rat myometrium with advancing gestation, and a decrease immediately before birth. Otun and collaborators [25] have described significantly elevated expressions of p38MAPK and ERK1 in the upper uterine segment at term and during labor, whereas ERK2 expression remained unchanged.

Proinflammatory cytokines increase exponentially in the uterus and cervix at the time for parturition $[1,8,26-28]$. 


\section{C-Fos}

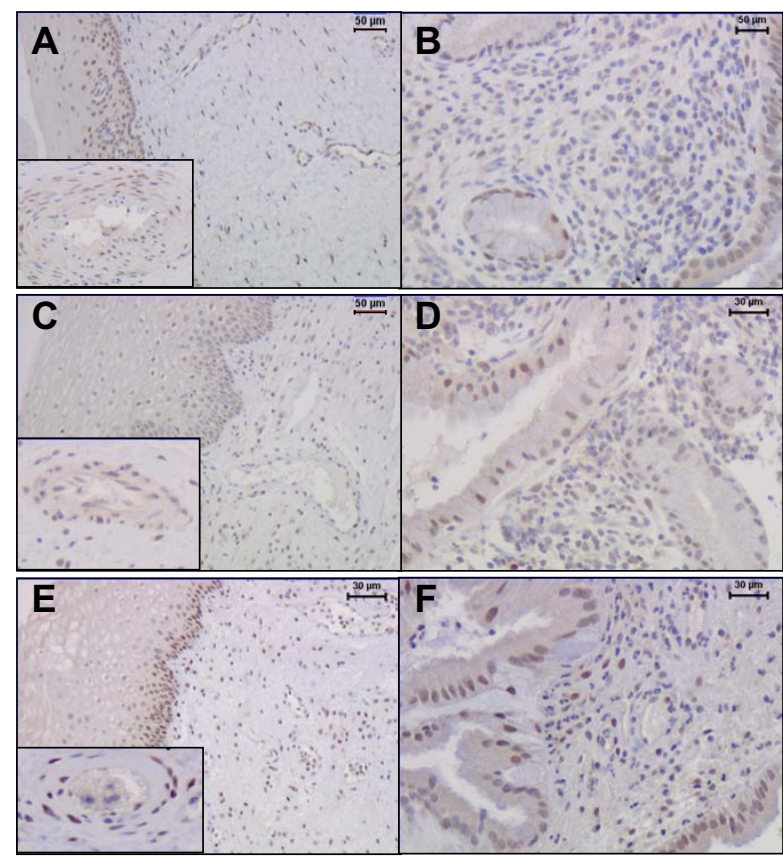

\section{C-Jun}

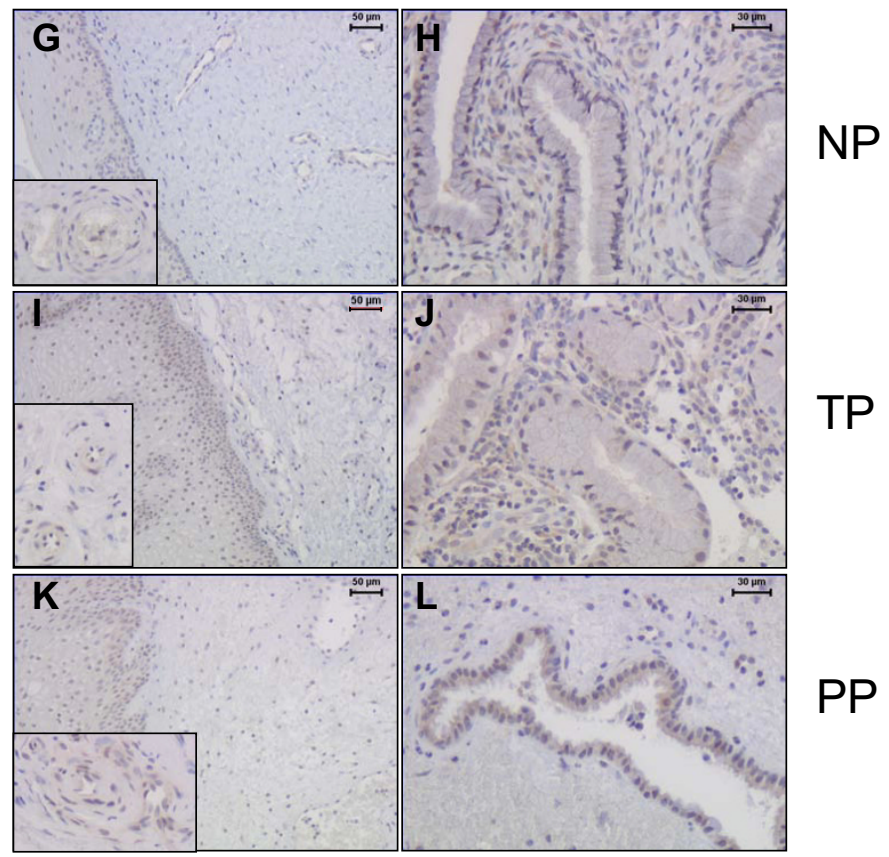

\section{Figure 4}

Representative sections showing the expression and distributions of c-Fos and c-Jun proteins (AP-I) in different cell types of cervical samples from non-pregnant (NP), term pregnant (TP) and postpartum (PP) groups. Stroma and blood vessels for c-Fos shown in in A, C, E and for c-Jun shown in G, I, K (magnification vein). Glandular epithelium and subepithelial mucosa area of stroma, shown for c-Fos in B, D, F and for c-Jun in $\mathrm{H}, \mathrm{J}$, L.

Mechanical stretch and hypoxia are physiological features in the uterine and cervical tissues during gestation, which escalate with labor [27]. Proinflammatory interleukin (IL)-1 $\beta$ and mechanical stretch act through MAPKs to increase inducible cyclooxygenase (COX)-2 and IL-8 expression in human uterine myocytes [27]. Evidence suggests that some effect of mechanical tension could be mediated through an increased IL-1 $\beta$ level [27]. The activation of MAPK signaling observed in the present study may therefore be caused by elevated proinflammatory cytokine levels, mechanical tension and hypoxia in the lower uterine segment.

A high density of p38MAPK was observed in vascular endothelium at term pregnancy. Previous studies have shown, that p38MAPK facilitates the adhesion of leukocytes to endothelial cell integrins, chemotaxis, leukocyte oxidative burst and release of IL-1 $\beta$ and elastase $[14,28]$. The increased endothelial p38MAPK expression in term pregnancy, therefore, indicates that p38MAPK facilitates leukocyte extravasation in the uterine cervix before parturition.
The glandular epithelium displayed a high immunostaining intensity particularly for pJNK and for p38MAPK, but without changes between the groups. Uterine glandular epithelium is known to be a source of cytokine synthesis [29]. The comparable pJNK and p38MAPK expressions could be due to the limited number of samples or, alternatively, depend on an unchanged rate of glandular epithelial pMAPK activation in cervical ripening at parturition.

Cervical stroma, which is composed of $70-80 \%$ fibrous connective tissue and 5-15\% smooth muscle [30] displayed increased immunostaining for all pMAPKs at term pregnancy, and an elevated pERK1/ 2 expression immediately after parturition. The expressions of proinflammatory transcription factors AP-1 and NFKB are increased in the cervical stoma at the time for parturition [31]. MAPK cascades, and estrogens, activate AP-1 and NFKB $[15,16,19,21,22]$. MAPKs and NFkB also activate the prostaglandin synthases phospholipase (PL) $\mathrm{A}_{2}$ and inducible COX-2 $[5,18,26,27]$. The collagen digesting enzyme metalloproteinase (MMP)-1 gene contains an AP-1 response 


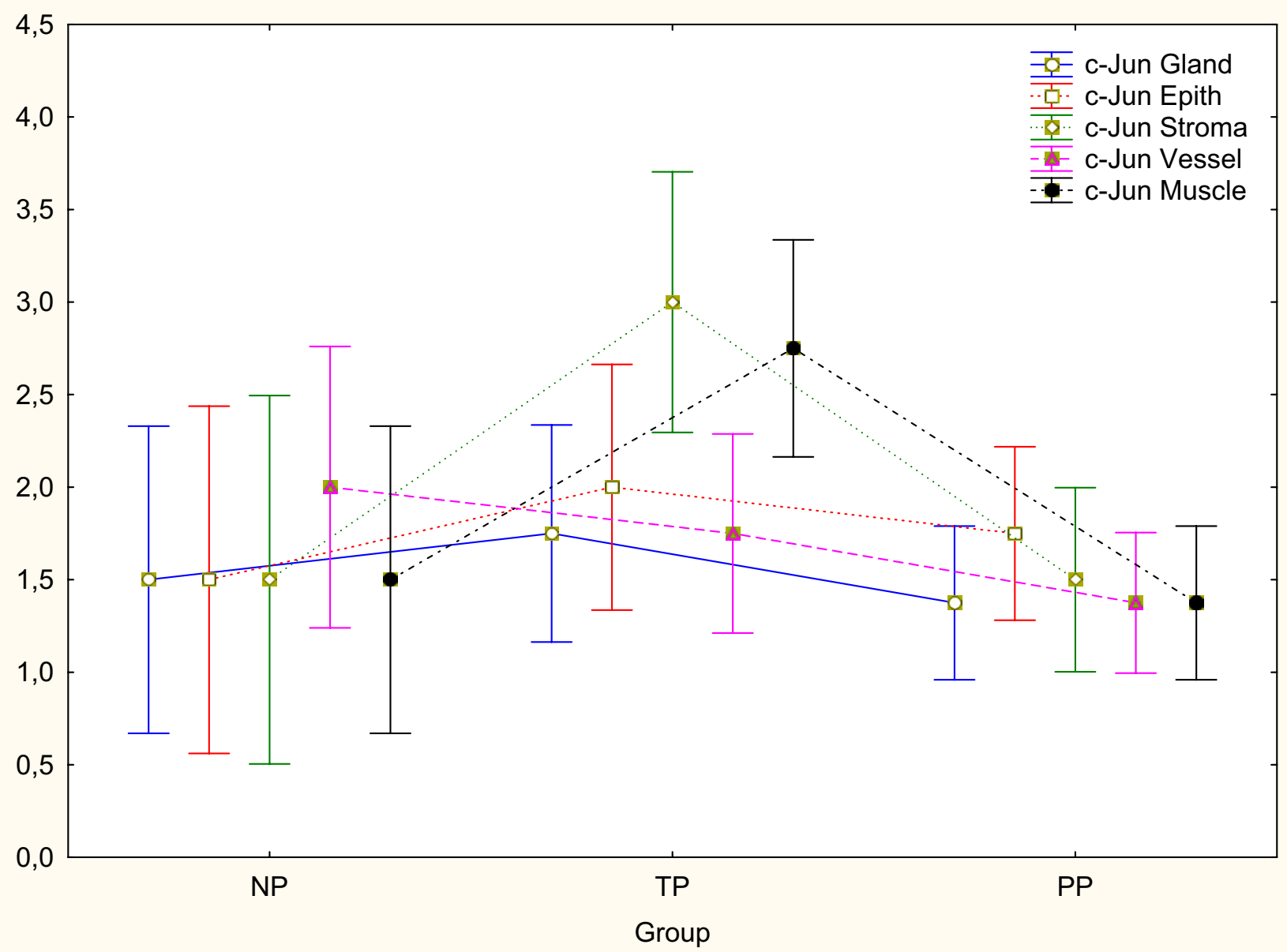

\section{Figure 5}

The immunostaining scores for c-Jun in different cell types in cervical biopsies from non-pregnant $(N P, n=2)$, term pregnant $(T P, n=4)$ and postpartum (PP, $n=8)$ groups. c-Jun immunoreactivity was significantly increased in cervical cervical stroma ( $P$ $<0.0 \mathrm{I})$ and smooth muscle $(\mathrm{P}<0.00 \mathrm{I})$ in TP as compared to NP group. Changes in vascular endothelium, squamous epithelium and glandular epithelium did not differ between the groups. Wilks lambda $=0.07 . F_{10,16}=4.03$.

element in its promoter region [32]. Thus, activation of MAPKs and their targets AP- 1 and NFKB in the uterine cervix could promote cervical ripening through an increased prostaglandin synthesis and an enhanced collagenolysis [6-8,26,27,31]. Nuclear ER mediated activation of MAPKs is unlikely. Despite an exponentially increased maternal plasma estradiol concentration reaching $200 \mathrm{nmol} / \mathrm{L}$ at term pregnancy, the total cervical nuclear ER level is markedly decreased, and inhibitory ER $\beta$ subtype enhanced, as compared to the non-pregnant state. This suggests that the nuclear ER mediated genomic response is very limited at parturition [7,12]. Our findings are in agreement with previous reports, which have showed that estrogens at high concentrations evoke early events such as inflamma- tory cell influx, activation of MAPK pathways, adenyl cyclase (AC) and protein kinase C (PKC) [15,33,34]. Estradiol at low concentrations, comparable to the circulating levels during the menstrual cycle, elicits nuclear ER genomic activation, which requires hours or days for maximal gene activation [15-17,21,22,34].

In conclusion, our observations indicate activation of MAPK cascades, and increased expressions of their targets transcription factors AP-1 and NFKB [31] in human uterine cervix before labor. These results suggest a role for MAPK phosphorylation in cervical ripening at parturition. The exact mechanism behind MAPK activation should be a topic for future studies. 


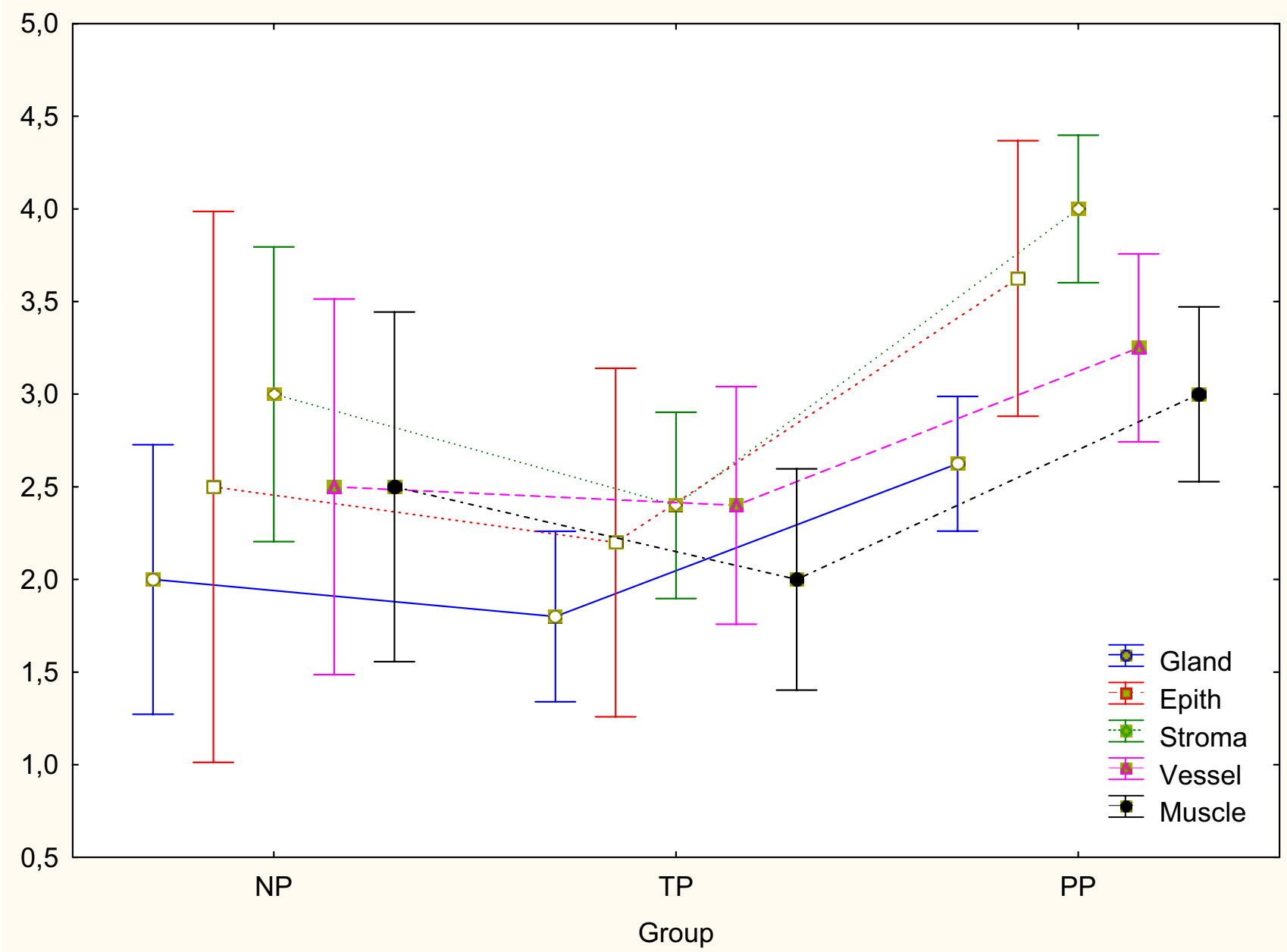

Figure 6

The immunostaining scores for c-Fos in different cell types in cervical biopsies from non-pregnant $(N P, n=2)$, term pregnant $(T P, n=4)$ and postpartum (PP, $n=8)$ groups. c-Fos immunoreactivity was significantly increased in cervical stroma $(P<0.0 \mathrm{I})$, squamous epithelium $(P<0.01)$ and glandular epithelium $(P<0.05)$ in $P P$ as compared to TP group. Changes in vascular endothelium and smooth muscle did not differ between the groups. Wilks lambda $=0.14 . F_{10,16}=2.70, P>0.05$.

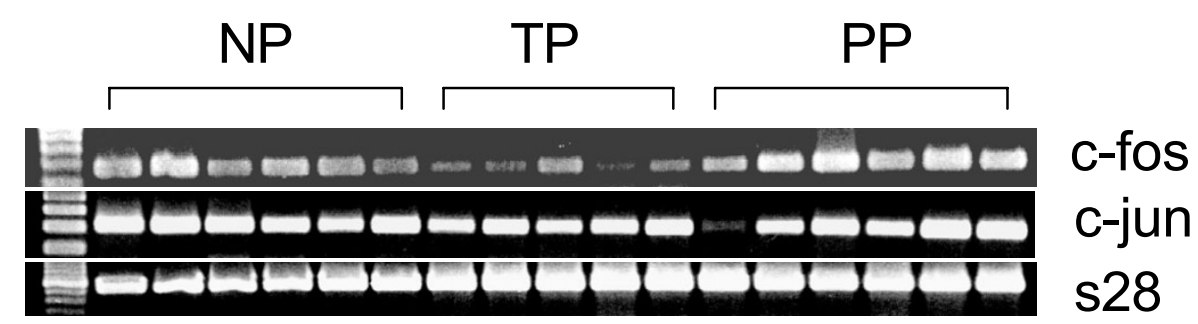

\section{Figure 7}

The presence of c-jun and c-fos mRNAs in 17 samples from the human uterine cervix as detected by RT-PCR analysis. Nonpregnant (NP, $n=6)$, term pregnant (TP, $n=5)$ and postpartum (PP, $n=6)$ groups. $28 \mathrm{~S}$ was used as an internal standard to enable the comparison of the amount of mRNA loaded to each well. 


\section{Acknowledgements}

We thank Dr Tomislav Vladic for comments and statistical advice.

\section{References}

I. Winkler M, Kemp B, Fischer DC, Duck P, Rath W: Expression of adhesion molecules in the lower uterine segment during term and preterm parturition. Microsc Res Tech 2003, I:430-444.

2. Junquiera LCU, Zugaib M, Montes G, Toledo O, Krisztan R, Shigihara $\mathrm{K}$ : Morphologic and histochemical evidence for the occurrence of collagenolysis and for the role of neutrophilic polymorphonuclear leukocytes during cervical dilatation. $\mathrm{Am} \mathrm{J}$ Obstet Gynecol 1980, I 38:273-28I.

3. Bokström H, Brännström M, Alexandersson M, Norström A: Leukocyte subpopulations in the human uterine cervical stroma at early and term pregnancy. Mol Hum Reprod 1997, I2:586-590.

4. Stygar D, Wang H, Vladic Stjernholm Y, Ekman G, Eriksson H, Sahlin $\mathrm{L}$ : Increased levels of matrix metalloproteinases 2 and 9 in the ripening process of the human cervix. Mol Hum Reprod 2002, 67:889-894.

5. Nagase $\mathrm{H}$ : The extracellular matrix of the uterus, cervix and fetal membranes. Synthesis, degradation and hormonal regulation. In Matrix metalloproteinases I, 2, and 3. Substrate specificities and activation mechanisms Edited by: Leppert PC, Woessner JF. New York: Perinatol Press; 1991:28-44.

6. Ekman G, Malmström A, Uldbjerg N, Ulmsten U: Cervical collagen: an important regulator of cervical function in term labor. Obstet Gynecol 1986, 67:633-636.

7. Stjernholm Y, Sahlin L, Malmström A, Barchan K, Eriksson HA, Ekman $\mathrm{G}$ : Potential roles for gonadal steroids and insulin-like growth factor I during final cervical ripening. Obstet Gynecol 1997, 90:375-380.

8. Denison FC, Calder AA, Kelly RW: The action of prostaglandin $E_{2}$ on the human cervix: stimulation of interleukin-8 and inhibition of secretory leukocyte protease inhibitor. Am J Obstet Gynecol 1999, 180:614-620.

9. Csapo A, Knobil E, van der Molen HJ, Wiest WG: Peripheral plasma progesterone levels during human pregnancy and labor. Am J Obstet Gynecol I 97I, I I 0:395-40 I.

10. Goodwin TM: A role for estriol in human labor, term and preterm. Am J Obstet Gynecol 1999, I 80:S208-2I3.

I I. Stygar D, Wang H, Vladic Stjernholm Y, Ekman G, Eriksson H, Sahlin L: Co-localization of estrogen receptor $\beta$ and leukocyte markers in the human cervix uteri. Mol Hum Reprod 2001, 7:881-886

12. Wang H, Stjernholm Y, Ekman G, Eriksson HA, Sahlin L: Different regulation of estrogen receptors $\alpha$ and $\beta$ in the human cervix at term pregnancy. Mol Hum Reprod 200I, 7:293-300.

13. Robinson MJ, Cobb MH: Mitogen-activated protein kinase pathways. Curr Opin Cell Biol I997, 9:|80-186.

14. Herlaar E, Brown Z: p38MAPK signalling cascades in inflammatory disease. Mol Med 1999, 5:439-447.

I5. Driggers PH, Segars JH: Estrogen action and cytoplasmic signaling pathways. Part II: the role of growth factors and phosphorylation in estrogen signaling. Trends Endocrinol Metab 2002, 1 3:422-428

16. Felty $Q$, Roy D: Mitochondrial signals to nucleus regulate estrogen-induced cell growth. Med Hypotheses 2005, 64: $|33-| 4 \mid$

17. Kato S, Endoh H, Masuhiro Y, Kitamoto T, Uchiyama S, Susaki H, Masushige S, Gotoh Y, Nishida E, Kawashima H, Metzger D, Chambon $\mathrm{P}$ : Activation of the estrogen receptor through phosphorylation by mitogen-activated protein kinase. Science 1995, 270: $|49|-1494$

18. Lin LL, Wartmann M, Lin AY, Knopf JL, Seth A, Davis RJ: cPLA is phosphorylated and activated by MAPK kinase. Cell 1993, 72:269-278

19. Whitmarsh AJ, Davis RJ: Transcription factor AP-I regulation by mitogen-activated protein kinase signal transduction pathways. Mol Med 1996, 74:589-607.

20. Chinenov V, Kerppola TK: Close encounters of many kinds: FosJun interactions that mediate transcription regulatory specificity. Oncogene 200I, 20:2438-2452.

21. Aronica SM, Katzenellenbogen BS: Stimulation of estrogen receptor-mediated transcription and alteration in the phosphorylation state of the rat uterine estrogen receptor by estrogen receptor, cyclic adenosine monophosphate, and insulin-like growth factor-I. Mol Endocrinol 1992, 7:743-752.

22. Improta-Brears T, Whorton AR, Codazzi F, York JD, Meyer T, McDonnell DP: Estrogen-induced activation of mitogen-activated protein kinase requires mobilization of intracellular calcium. Proc Natl Acad Sci USA 1999, 96:4686-469l.

23. Wang $H$, Eriksson $H$, Sahlin L: Estrogen receptor $\alpha$ and $\beta$ in the female reproductive tract of the rat during the estrous cycle. Biol Reprod 1999, 63: |331-1340.

24. Rusycky AL: Down-regulation of mitogen-activated protein kinase cascade immediately before parturition in rat myometrium. I Soc Gynecol Invest 1998, 5:304-310.

25. Otun HA, MacDoughall MW, Bailey J, Europe-Finner GN, Robson SC: Spatial and temporal expression of the myometrial mitogenactivated protein kinases p38 and ERK I/2 in the human uterus during pregnancy and labor. J Soc Gynecol Invest 2005, 1 2: $185-190$.

26. Allport VC, Pieber D, Slater DM, Newton R, White JO, Bennett PR: Human labour is associated with nuclear-factor kappaB activity which mediates cyclo-oxygenase- 2 expression and is involved with the 'functional progesterone withdrawal'. Mol Hum Reprod 200I, 7:581-586.

27. Sooranna SR, Engineer N, Loudon JA, Terzidou V, Bennett PR, Johnson MR: The mitogen-activated protein kinase dependent expression of prostaglandin $H$ synthase- 2 and interleukin-8 messenger ribonucleic acid by myometrial cells: The differential effect of stretch and interleukin-I $\beta$. J Clin Endocrinol Metab 2005, 90:3517-3527.

28. Detmers PA, Zhou D, Polizzi E, Thieringer R, Hanlon WA, Vaidya S, Bansai $V$ : Role of stress-activated mitogen-dependent neutrophil adhesion and the adhesion-dependent oxidative burst. J Immunol 1998, I6 I:1921-1939.

29. Singer CF, Marbaix E, Kokorine I, Lemoine P, Donnez J, Eeckhout Y, Courtoy PJ: Paracrine stimulation of interstitial collagenase (MMP-I) in the human endometrium by interleukin I $\beta$ and its dual block by ovarian steroids. Proc Natl Acad Sci USA 1997, 94: $10341-10345$

30. Danforth DN: The distribution and functional activity of the cervical musculature. Am J Obstet Gynecol 1954, 68: | 26 I- | 27|.

31. Vladic Stjernholm Y, Stygar D, Månsson C, Åkerberg S, Masironi B, Wang H, Ekman-Ordeberg G, Sahlin L: Factors involved in the regulation of cervical ripening in humans. J Reprod Biol Endocrinol 2004, 2:74.

32. Jonat C, Stein B, Ponta H, Herrlich P, Rahmsdorff $\mathrm{H}$ : Positive and negative regulation of collagenase gene expression. Matrix Suppl 1992, I:I45-155

33. Pietras RJ, Szego CM: Specific binding sites for oestrogen at the outer surface of isolated endometrial cells. Nature 1977 , 265:69-72.

34. Borras C, Gambini J, Gomes-Cabrera MC, Sastre J, Pallardo FV, Mann GE, Vina J: I7 $\beta$-estradiol up-regulates Iongevity-related, antioxidant enzyme expression via the ERKI and ARK2/NF $\kappa B$ cascade. Aging Cell 2005, 4: I I3-I I8.

Publish with Bio Med Central and every scientist can read your work free of charge

"BioMed Central will be the most significant development for disseminating the results of biomedical research in our lifetime. "

Sir Paul Nurse, Cancer Research UK

Your research papers will be:

- available free of charge to the entire biomedical community

- peer reviewed and published immediately upon acceptance

- cited in PubMed and archived on PubMed Central

- yours - you keep the copyright
BioMedcentral 